\title{
The Impossibility to Protect? Media Narratives and the Responsibility to Protect
}

Kjell Føllingstad Anderson

NIOD Institute for War, Holocaust and Genocide Studies

Ingjerd Veiden Brakstad

Department of Historical Studies, Norwegian University of Science and Technology

Follow this and additional works at: https://digitalcommons.usf.edu/gsp

\section{Recommended Citation}

Anderson, Kjell Føllingstad and Brakstad, Ingjerd Veiden (2016) "The Impossibility to Protect? Media Narratives and the Responsibility to Protect," Genocide Studies and Prevention: An International Journal: Vol. 9: Iss. 3: 96-115.

DOI:

http://dx.doi.org/10.5038/1911-9933.9.3.1331

Available at: https://digitalcommons.usf.edu/gsp/vol9/iss3/9

This Articles is brought to you for free and open access by the Open Access Journals at Digital Commons @ University of South Florida. It has been accepted for inclusion in Genocide Studies and Prevention: An International Journal by an authorized editor of Digital Commons @ University of South Florida. For more information, please contact digitalcommons@usf.edu. 


\title{
The Impossibility to Protect? Media Narratives and the Responsibility to Protect
}

\author{
Kjell Anderson \\ NIOD Institute for War, Holocaust and Genocide Studies \\ Amsterdam, The Netherlands \\ Ingjerd Brakstad \\ Department of Historical Studies, Norwegian University of Science and Technology \\ Trondheim, Norway
}

\begin{abstract}
The media plays an important role in communicating mass atrocities to audiences across the globe. This article critically examines how journalists' framing of mass atrocities may contribute to public discourse on the responsibility to protect principle, in particular the perceived obligation to intervene in cases of mass atrocities. It will draw from a broader conceptual framework on bystander responses to mass atrocities and utilise evidence from the analysis of newspaper accounts of the Rwandan and Bosnian genocides. It will argue that, in some cases, media narratives may actually erode political will and encourage passivity in response to mass atrocities.
\end{abstract}

Keywords: media, mass atrocities, responsibility to protect, genocide, bystanders, Rwanda, Bosnia.

\section{Introduction}

Our intuitive understanding of mass media is that it makes the world a smaller place. We are aware of events on the other side of the globe in a way that would be impossible without a globalized, accessible media. Yet this broadening of perspective does not inevitably lead to actionable empathy. Geographical, cultural, and emotional distance continue to render victims remote and diminished. In fact, in some cases, the narratives adapted by the media may actually contribute to the distancing of victims, figuratively making the world larger. Victims who are characterized as the objects of inexorable historical forces, in distant and dangerous contexts, are unlikely to be assisted by bystanders.

This article will consider the role of the media in shaping discourse around mass atrocities (genocide and crimes against humanity). It will argue that the media, in some cases, encourages passivity in response to mass atrocities - it does not compel action under the responsibility to protect but rather provides justifications for inaction. It will draw from Brakstad's research on Norwegian and international media narratives relating to the Rwandan and Bosnian Genocides. These data will then be interpreted through Anderson's conceptual framework for bystander techniques of neutralization. Finally, we will examine the policy implications of these findings in terms of the responsibility to protect and the will of bystander states to intervene in defence of others.

\section{The Media and Mass Atrocities}

In covering the wars and genocides in Rwanda and Bosnia, the media played the role of both near and distant bystander. Journalists on the ground were at times direct bystanders to the genocidal violence, whereas editors, commentators, and journalists writing about the violence from home were, like the rest of us, distant bystanders. Initially we will look at some of the ways the violence was mediated: how the events were understood and explained, and what narratives the media collectively may have been creating or re-affirming.

The media coverage of the atrocities in Rwanda and, to a lesser extent, Bosnia has been repeatedly criticized. In criticism of the failure of international media in Rwanda, the coverage of Bosnia is often used as a comparison to highlight how the coverage of Rwanda had a lower priority and impact than Bosnia. ${ }^{1}$ Undoubtedly, the coverage of Bosnia was both broader and more nuanced than the coverage of Rwanda.

${ }^{1}$ One example of this perspective is Myers, Garth, Thomas Klak and Timothy Koehl. 1995. "The Inscription of Difference: News Coverage of the Conflicts in Rwanda and Bosnia." Political Geography Vol. 15, No. 1, 21-46. 
However, if we approach the comparison from a different perspective, we find certain common narratives that framed how journalists and others wrote about the mass violence in both countries. In Rwanda the dominant narrative was overwhelmingly of perceived tribal war and, secondarily, of Western failure. Within these narratives there were closely related sub-narratives. The one-sided genocide was seen as a two-sided war, involving the entire Rwandan population. No distinctions were initially made between soldiers and civilians, in other words the so-called shooting war was not distinguished from the genocide. The violence was seen as both a sudden eruption and an historical inevitability.

In the coverage of Bosnia there were several narratives at play simultaneously, but the predominant image was of a powder-keg (the powder in this case being historical nationalist animosity) lit by the nationalist emotions that were finally breaking free after being supressed during the Tito-years. In short, we do find the same narrative dynamics in both Bosnia and Rwanda with sudden violence breaking out after being penned up for centuries and unfolding in faraway, almost mythical places-Sub-Saharan Africa and the classical European Other, the Balkans.

The examples we use in our analyses are drawn from a survey of Norwegian newspapers' coverage of Rwanda between 6 April and 31 December 1994 and of Bosnia between 2 April 1992 and 31 December 1995. The sources are two of the largest Norwegian newspapers and the leading Norwegian news agency, Aftenposten, Verdens Gang (VG) and Norsk Telegrambyrå (NTB). ${ }^{2}$ These papers also included articles from international wire services and are broadly representative of the media narratives found in other Western countries at the time. ${ }^{3}$

After analyzing the relevant articles (see footnote 2 for methodology and selection criteria), we could identify two main narratives for Rwanda and three for Bosnia. The coverage of Rwanda was overwhelmingly dominated by an understanding of the violence as tribal war but secondly by the failure of the outside world to stop the violence. In the coverage of Bosnia, there were three main patterns of framing: 1) the break up and resulting war(s) in the former Yugoslavia was the result of cynical, criminal politicians playing on nationalist sentiments to manipulate their own population, 2) the war in Bosnia and especially the siege of Sarajevo was seen as an attack-and, because of the lack of intervention - the subsequent downfall of Europe, and 3) the war was an allagainst-all quagmire, the inevitable result of ancient hatreds. In this article we focus on the latter narrative, where the culturally constructed Balkans dominated the understanding and coverage of the genocidal war.

We do not aim to give a full analysis of the coverage of either event, but rather to show how certain frames created by the media may have served to neutralize the will to intervene to assist

\footnotetext{
${ }^{2}$ The initial data gathering was done by using the search engine Retriever-collecting every article in the relevant time periods that included the terms "Bosnia*" or "Rwanda*." This preliminary search gathered 874 articles and news bulletins mentioning Rwanda and - unsurprisingly - the significantly higher number of 12,734 mentioning the word "Bosnia." In the case of Rwanda every article in this first search was relating in one way or the other to the war and/or the genocide, and so every article was kept for further analysis. In the case of Bosnia, however, a small portion of the articles turned out to be about sports, Eurovision or other events other than the ongoing violence. There was also a significant overlap in that several of the articles were almost identical. This overlap was the result of different newspapers buying the same articles from international news agencies like Reuters and that the local news agency Norsk Telegrambyra (NTB) would publish several (between two and four) versions of the same article, with minor edits. This overlap accounted for a significant part of the 7,207 articles and bulletins from NTB, and for a lower but not insignificant number of the newspaper articles. Filtering out these double, triple and sometimes quadruple results, left 3,000 articles about Bosnia and Rwanda for further analyses. All the results for Rwanda were relating to the war and/or genocide. The total number of 874 articles was manageable to read through, so no further break down of the results were necessary. In contrast, the coverage of Bosnia was, in addition to spanning a larger time frame, far broader. After reading through the results for Bosnia, it was clear that further articles could be filtered out. For example there was an intense national Norwegian political debate on how to best accommodate Bosnian refugees. This debate, while obviously being related to the situation in Bosnia, was not about the war and genocide but about national politics in Norway. The substantial coverage of Bosnians in Norway and other similar cases where the word Bosnia was figuring prominently in the headlines as well as throughout the articles, is not relevant in this case and was therefore not included in the analyses.

${ }^{3}$ For critical analyses of the media coverage of Bosnia, see for example Cushman, Thomas and Stjepan G. Mestrovic, editors. 1996. This Time We Knew. Western Responses to Genocide in Bosnia. New York: New York University Press; and Sadkovich, James J. 1998. The U.S. Media and Yugoslavia, 1991-1995. Westport: Praeger Publishers. For Rwanda, see Thompson, Allan, editor. 2007. The Media and the Rwanda Genocide. London: Pluto Press; and Gustafsson, Tommy. 2010. "Swedish television News Coverage and the Historical Media Memory of The Rwandan Genocide." Scandia Vol. 76, No. 2, 80-98.
} 
victims of mass atrocities in Rwanda and Bosnia. A media framing that over-communicated place (Africa and the Balkans) and history contributed to an understanding of the political violence as natural or inherent as well as historically inevitable.

\section{Bystanders and the Techniques of Neutralisation ${ }^{4}$}

Before analyzing media discourse in response to mass atrocities we will first consider the narratives and social-psychological mechanisms which inform bystander behaviour. Through understanding bystander narratives we gain a framework for the analysis of media narratives in respect to their effect on the bystander will to intervene. Bystanders (in this context, those who witness mass atrocities but do not respond) may be divided into near bystanders (those present at the location of victimisation) and distant bystanders (those not present). ${ }^{5}$ Anderson draws from Sykes and Matza's neutralization drift theory to argue that certain rationalizations, "techniques of neutralization" are employed by perpetrators as vocabularies of motive to reframe and justify their perpetration. ${ }^{6}$ Such techniques enable perpetrators to maintain their moral self-identity, all the while committing immoral acts such as violating the moral prohibition on murder.

We hypothesize that bystanders also use techniques of neutralization to neutralize the moral norm of intervening to assist others in danger. This self-rationalization renders their decision not to intervene acceptable, thus evading cognitive dissonance and the moral judgements of others. Such inaction often stands in stark contradiction to moral norms requiring action to assist suffering others and to confront wrongful acts. This is not to say that bystanders are inherently moral actors, in fact they may, by default, seek out excuses for inaction. Moral neutralization then, we posit, also functions as a means of explaining immoral acts and omissions to others.

In situations of moral disengagement, where the bystander convinces themselves that moral rules are not applicable in that situation, the responsibility for intervention will lower, as will the emotional consequences (guilt) of non-intervention. ${ }^{7}$ Moral neutralization facilitates moral disengagement by contextualizing the situation in a manner which removes or reduces the moral imperative to act.

There are five categories of bystander techniques of neutralization: first, the denial of the victim; second, the claim of ignorance; third, the claim of futility; fourth, the claim of jeopardy; and, fifth, the denial of responsibility. ${ }^{8}$ These bystander techniques may be applied to individual bystanders or to states.

We will briefly examine each of these techniques. Firstly, the denial of the victim discredits victimization by positing that the victims are so foreign that they cannot be understood, that they are responsible for their own suffering, or that they are so numerous to be utterly incomprehensible. Distant bystanders often condemn victims through the subtle discourse of exoticism: the victims are very different from Us, therefore our moral obligations towards Them are diminished. In the most extreme form bystanders might even deny the humanity of the victims, though this is not often present in media accounts in bystander states. More commonly, bystanders may argue that the victims brought violence on themselves either through their own violence or provocations, or their

\footnotetext{
${ }^{4}$ The material in this section is drawn substantially from Kjell Anderson's 2011 PhD thesis The Dehumanisation Dynamic: A Criminology of Genocide. This thesis forms the basis for the forthcoming volume Killing Without Consequence.

${ }^{5}$ Of course some bystanders who are not present at the scene of the violence are not very distant. One may consider, for example, the position of family members of the victims, or those who hear victims directly recounting their victimization. This distance from the scene of the crime is even further reduced for those who are close to the victim and present in the country where the violence is taking place. Such bystanders may be in a position of potential victimization themselves.

${ }^{6}$ Anderson, Kjell. 2011. The Dehumanisation Dynamic: A Criminology of Genocide. PhD thesis. Galway: Irish Center for Human Rights, 8, and Sykes, Gresham M. and David Matza. 1957. "Techniques of Neutralization: A Theory of Delinquency." American Sociological Review Vol. 22, No. 6, 664-670.

${ }^{7}$ Piliavin, Irving M., Judith Rodin, and Jayne Allyn Piliavin. 1969. “Good Samaritanism: An Underground Phenomenon?” Journal of Personality and Social Psychology Vol. 13, No. 4, 289-299.

${ }^{8}$ Economist Albert Hirschman argues that people who do not want to act cite the futility, perversity, and jeopardy of proposed measures. Samantha power applies this theory to the United States' response to genocide and I am melding this idea with my own modified form of Skykes and Matza's neutralization-drift theory. See Power, Samantha. 2002. A Problem from Hell: America in the Age of Genocide. New York: Basic Books, 125.
} 
1. Denial of the Victim
a. Exoticism
b. Culpability
c. Statistical abstraction

2. Claim of Ignorance

a. Specific ignorance (not enough info. about specific situation for certitude)

b. General ignorance (lack of knowledge about cultural and geopolitical context)

3. Claim of Futility
a. Inevitability
i. Metaphysical
ii. Historical
b. Ineffectiveness
i. Powerlessness
ii. Counter-Productivity

4. Claim of Jeopardy
a. Geographical
b. Tribal

5. Denial of Responsibility

Figure 1. Bystander Techniques of Neutralization.

inability to accept reasonable alternatives to violence. Apportioning the blame to all sides is also a means to avoid involvement. A final form of the denial of the victim is the abstraction of victims. Paradoxically, victimization en masse may reduce our perception of individual victimization. In a sense the denial of the victim represents our inability to come to terms with victimization itself.

Secondly, through the claim of ignorance passive bystanders often claim that the victimization they are witnessing is not clear-that there is not enough information available for reasonable certitude. The apparent uncertainty or decision paralysis of other bystanders further reinforces this shield of ignorance. When in dialogue with other doubting bystanders, a type of group-think may take hold.

A group of people (or perhaps even states) may also exhibit pluralistic ignorance where a subconscious decision is taken to ignore the victimization at hand sending cues to other bystanders that the apparent victimization is actually going unwitnessed or not even taking place at all. ${ }^{9}$ As early as 1942 the Allies began receiving reports of the Holocaust but decision-makers denied and suppressed this information because it was deemed not reliable or incomplete. ${ }^{10}$ Similarly, American diplomats on the ground in Rwanda received regular briefings on RTLM hate radio broadcasts and the training of extremist militias in Rwanda but failed to take action. ${ }^{11}$

American policy-makers in Washington took this willful blindness a step further by arguing in a discussion paper from the Office of the Secretary of Defence, "Be Careful. Legal at State was worried about this yesterday-Genocide finding could commit the USG [United States Government] to actually 'do something'."12 State Department officials advised the USG to use the phrase "acts of genocide" as otherwise "our credibility will be undermined with human rights groups and the general public, who may question how much evidence we can legitimately require before coming to a policy conclusion."13 Samantha Power argues that this avoidance of

\footnotetext{
9 Staub, Ervin. 2003. The Psychology of Good and Evil. New York: Cambridge University Press, 74, 87-89.

${ }^{10}$ Power, Problem from Hell, 35.

${ }^{11}$ Dallaire, Romeo, Frank Chalk, Kyle Matthews, Carla Barqueiro, and Simon Doyle. 2009. Mobilizing the Will to Intervene:

Leadership and Action to Prevent Mass Atrocities. Montréal: Montréal Institute for Genocide Studies, Concordia University.

${ }^{12} \mathrm{Ibid}$, "Will to Intervene," 102.

${ }^{13} \mathrm{Ibid}$, "Will to Intervene," 103.
} 
the term genocide means that policy-makers "can in good conscience favour stopping genocide in the abstract, while simultaneously opposing American involvement in the moment."14 Beyond the specific circumstances of a situation, bystanders may also claim ignorance on the basis of distance-cultural or physical.

Thirdly, through the claim of futility bystanders may argue that intervention to assist victims would be futile due to the inevitability of violence or the ineffectiveness of countermeasures. This inevitability may be rooted in the historicity of evil or even the metaphysical certainty of continuing evil. Bystanders may also argue that to take action would be too difficult or too complicated. Moreover, intervention might require power and resources that are simply unavailable. A variation of this justification is the idea that intervention would be existentially fruitless: supernatural or human evil are real and immutable characteristics of human existence so intervention would be pointless. They may also claim that intervention would be counter-productive-that it would only make matters worse, exacerbating the humanitarian plight of the victims.

Fourthly, the claim of jeopardy frames intervention as too risky. This discourse posits that intervention could expose the bystanders themselves to potential victimization. In Western countries considering intervention in Africa or Asia, jeopardy is often portrayed as geographical (the landscape itself is dangerous) or tribal (the people have culturally-ingrained and incomprehensible violent traits). Both the tribal and geographical aspects of the claim of jeopardy are closely related to notions of exoticism, which themselves neutralise empathy for victims. For example, Kenneth Calder, former Assistant Deputy Minister for Policy at the Canadian Department of National Defence recalls Canada's reaction to the possibility of intervening militarily in Rwanda in 1994: "It was just a kind of gut reaction. People were saying, 'When we deploy to Africa, we have problems more so than elsewhere'."15 This perception of an entire continent was rooted more in cultural belief than tactical assessment.

Finally, bystanders justify their inaction by arguing that others are in a better position to intervene, therefore are more responsible for the consequences of non-intervention. Social psychological experiments show that individuals are much less likely to intervene if there are other non-intervening individuals present-they are effected by pluralistic ignorance and diffuse moral responsibility. ${ }^{16}$ Policy-makers may even utilize the law as a means to argue that others are more responsible.

The greater the number of techniques of neutralization effectively invoked, the weaker the moral obligation to intervene. According to psychologist Ervin Staub, bystanders are also more likely to help if it is socially appropriate (we seek to behave in a manner consistent with other people's expectations). ${ }^{17}$ Moreover, intervention requires action, which often entails greater personal risks than inaction. In a sense then, the impulse to intervene is not driven by empathy but rather by social expectations and contingencies.

States are both distinct institutional personalities as well as the aggregate of millions of individuals. Therefore, bystanding behaviour in states is the product of the individual characteristics of leaders, the perceived interests of states (as institutionalized in government structures), and the decision-making of other states. Individual bystanders, whether they are near bystanders or distant bystanders, all want to avoid moral guilt for their failure to respond to the suffering of others. This may be especially true for leaders who may utilize techniques of neutralization both for politicalinstrumental reasons and also for the sake of their own cognitive integrity (maintaining their view of themselves as good people). However, the weight of responsibility on long-distance bystanders is undoubtedly far less than that of people who actually witness killing in their midst.

\footnotetext{
${ }^{14}$ Power, Problem from Hell, xviii.

${ }^{15}$ Dallaire et al, “Will to Intervene," 69.

${ }^{16}$ The experiments of Latané and Darley found that with an increasing number of bystanders there was a decreasing willingness to help. However, as Staub asserts, there are also contradictory findings with regards to the relevance of the diffusion of responsibility as a determining factor in intervention. See Staub, Ervin. 2003. The Psychology of Good and Evil. New York: Cambridge University Press, 74. For more on the experiments of Latane and Darley, see Latane, Bibb and John Darley. 1970. The Unresponsive Bystander: Why Doesn't He Help? New York: Appleton.

${ }^{17}$ Staub, Psychology, 125-130.
} 
Observing other peoples' suffering is unpleasant, so near bystanders will either help or seek to leave the scene..$^{18}$ Not helping others may also bear certain internal costs (guilt) or external costs (social or even legal sanctions where so-called Good Samaritan laws are in place). The bystander techniques of neutralization counteract the moral imperative to assist others. We hypothesize that this makes the bystander techniques of neutralization, as manifested in public discourse, a mediating factor for political will. As our analysis will demonstrate some of these techniques of neutralization were embedded in media narratives in the reporting on mass atrocities in Bosnia and Rwanda.

\section{Media Analysis: Rwanda and Bosnia}

The media framed the Rwandan and Bosnian atrocities in a manner which echoed several of the bystander techniques of neutralization. In our analysis of the reporting of the Rwandan and Bosnian genocides, our objective is to focus less on the actual objective reality of media reportage and more on its implications and rootedness in stereotypical discourses. A general observation on the reporting from both Rwanda and Bosnia is that reporters got closer to accurately reporting what happened as real events when they were simply describing what was happening rather than trying to explain it. These more descriptive reports tend to approach genocide and attacks on civilians as real events that actually took place.

On the other hand, when these events were analyzed by journalists or editors at their desks at home, they were often abstracted to a level where there were no longer real perpetrators operating in a recognizable world. We are now reading about history unfolding and Europe dying (in the case of Bosnia) rather than real people being murdered by other real people for morally unacceptable but still comprehensible reasons. An armed attack on civilians can be both understood and stopped; in contrast, history unfolding in a mythical landscape removed from reality is incomprehensible and inexorable. As readers we are left to be horrified by tribal hatreds and collective insanity spurred on by history itself, but it is difficult to relate to this drama as something tangible taking a place in a comprehensible world.

In other words, when the events were framed using the Place and History frames mentioned above, bystander understandings of the situation and the responsibility to intervene were also altered. These history and place frames touch on several of the bystander techniques of neutralization, including the denial of the victim, claim of ignorance, claim of futility, and claim of jeopardy.

\section{Media framing and Master Narratives}

Media framing can be defined simply as a way of "making sense of relevant events and suggesting what is at issue."19 The way an event is framed is thus largely determined by previously existing narratives. Broadly speaking, the narratives on war and mass violence can be divided into two categories: one political and one cultural. In the first case, the events are seen as rational-there are political reasons behind the violence and the perpetrators are concerned with political or financial gain. The instigators are seen as cynically playing on national or ethnic sentiments to secure their own power and the violence on the ground is perceived as orchestrated from above. ${ }^{20}$

In the cultural frame we find the stereotype of ancient ethnic or tribal hatreds. According to this understanding the violence is tribal, emotional and primordial. It is not controlled from above; rather, it springs out of a deep resentment in the population as a whole. It is violence from below. These two narratives are simplistic versions of academic theories on ethnic violence, the first roughly reflecting instrumentalist theories and the latter drawing from the primordialist

\footnotetext{
${ }^{18} \mathrm{Ibid}, 82$.

${ }^{19}$ Sidahmed, Abdel Salam, Walter C. Soderlund, and E. Donald Briggs. 2010. The Responsibility to Protect in Darfur: The Role of Mass Media. Plymouth, U.K.: Lexington Books, 46.

${ }^{20}$ See Mueller, John. 2000. “The Banality of 'Ethnic War'.” International Security Vol. 25, No. 1; Kaufman, Stuart J. 2006.

"Symbolic Politics or Rational Choice? Testing Theories of Extreme Ethnic Violence." International Security, Volume 30, Number 4, 45-86; Kaufman, Stuart J. 2001. Modern Hatreds. The Symbolic Politics of Ethnic War. Ithaca: Cornell University Press; Gagnon, Jr., V. P. 2004. The Myth of Ethnic War. Serbia and Croatia in the 1990s. Ithaca: Cornell University Press.
} 
tradition. ${ }^{21}$ We will be focusing on how the media created narratives that drew on an extremely simplified version of the primordialist view and how place and history constituted frames that reinforced the bystander techniques of neutralization.

By assigning the events to an almost unreal universe through place and history framing, the violence was implicitly, and often explicitly, portrayed as a natural and normal state when in fact genocidal violence was the historic exception in both cases. ${ }^{22}$ The narrative of ancient hatred, cyclic violence and hopelessness are all components of the Western master narratives about both Africa, traditionally inhabiting the role of the Dark Continent, and the Balkans, serving as the dark part of the European continent. ${ }^{23}$

A master narrative says little, if anything, about the events it supposes to describe but more so about the society that produces it. The media narratives on mass violence are both socioculturally generated and reflective of existing culture. ${ }^{24}$ These narratives are shaped both by how we view the Other and by how we see ourselves vis-à-vis the other. In Inventing Western Civilization anthropologist Thomas C. Patterson has identified an obsession with peoples and places categorized as uncivilized as an essential feature of civilization..$^{25}$

It is often assumed that the reproduction of images and textual impressions of suffering in the media actualize suffering and bring the audience into direct contact with the suffering of others; this so-called empathy framing is crucial to creating a CNN effect ${ }^{26}$ in support of victims of human rights abuse, thus contributing to a demand for robust policy responses, including military intervention. ${ }^{27}$ As we will argue, however, images of suffering-when framed as a constant or as inevitable - can paradoxically also lead to a greater distance between the observer and the observed, thereby implicitly providing an argument for non-intervention. Place and history framing serves as a technique of neutralization for the bystanders (both for the producers and the consumers of these narratives) by framing the events as ultimately inevitable, consequently denying the victims and inculcating notions of jeopardy.

The cliché of ancient ethnic or tribal hatreds was the dominant narrative in the coverage of Rwanda and to a significant (albeit less dominant) degree in Bosnia. In the following analysis we will highlight examples of two closely related components of this stereotype, history and place, and discuss how these two frames created an image of apathetic inevitability.

When comparing the media coverage of the wars and genocides in Bosnia and Rwanda, it is often observed that where Rwanda was portrayed as a place of darkness and violence, far removed from Us and from any of the celebrated values that are perceived as enlightened and Western, Bosnia was seen as part of Europe. Consequently, Bosnia's Europeanness raised the spectre of The Holocaust, barbarous violence in the midst of European civilization. The attack on Sarajevo especially was seen as an attack on Europe itself. However, it is clear that parallel with this interpretation there existed a narrative that saw Bosnia not as Europe, but as the Balkans; and the Balkans were-much like Rwanda-seen as exotic, inherently dark, backwards and violent. By way of contrast the ideal Europe, the Europe imaginary, was a place of civilization, free from the tribalism, irrationalism, and conflict which characterised much of the world outside of Europe.

\footnotetext{
${ }^{21}$ The primordialist tradition is often attributed to Clifford Geertz' 1963 book Old Societies and New States. For a critical analyses of primordialism and political mass violence, see Kaufman, Modern Hatreds.

${ }^{22}$ Even though mass violence had occurred before the 1990s both in Rwanda and in the Balkans, genocide was the exception, not the rule.

${ }^{23}$ For more on the cultural construction of the Balkans, see Todorova, Maria. 1994. "The Balkans: From Discovery to Invention." Slavic Review Vol. 53, No. 2, 453-482; Todorova, Maria. 1997. Imagining the Balkans. Oxford: Oxford University Press; and Goldsworthy, Vesna. 2012. Inventing Ruritania: The Imperialism of the Imagination. Oxford: Oxford University Press.

${ }^{24}$ Fairclough, Norman. 1995. Media Discourse. London: Hodder Education, 34.

${ }^{25}$ Patterson, Thomas C. 1997. Inventing Western Civilization. New York: Monthly Review Press, 21.

26 Livingston, Steven. 1997. "Clarifying the CNN Effect: An Examination of Media Effects According to Type of Military Intervention." Research Paper R-18. Cambridge, MA: The Joan Shorenstein Center, John F. Kennedy School of Government, Harvard University.

${ }^{27}$ Sidahmed et al, editors, The Responsibility To Protect, 56.
} 
Hearts of Darkness

"Rwanda, May 1994. A journey in human cruelty." 28

"There is a hatred between people down there that is difficult for us to comprehend." ${ }^{29}$

In the early spring of 1994, most journalists and outside news consumers had very limited, if any, knowledge about Rwanda. The country was, in short, a very distant place. Once the events in Rwanda started making headlines, this distance increased by framing the genocide as an almost natural result of the county's locality and (perceived lack of) historic development. Not only the geographical distance, but also the cultural and historical distance was systematically over-communicated. The war and genocide were perceived not as political, but as tribal, and the perpetrators were even described as warriors. Words like tribal and warrior immediately invoke certain images for readers and conjure an exotic, almost mythical place-a dark place of perpetual violence and suffering for its population, producing a guilty conscience but also resignation for us, the distant observers.

Already at the very beginning of the genocide, the media established that the violence would be gruesome and a lot of people would die. Based on a history of violence, "mass murder and revenge" that had previously taken place in the country, "there is little reason for hope." ${ }^{30}$ Rwanda was to be inundated by an unstoppable force of incomprehensible nature.

This terminology and the broader narrative of a hopeless and helpless Africa remind the reader of the distance. Instead of bringing the events closer to us we are instead left with the impression that there are places that are simply outside our comprehension. We, the distant bystanders, cannot possibly understand what is happening in Rwanda.

The political mass violence of April 1994 was seen as yet another example of a cycle of violence: "Throughout history Hutu and Tutsi have been slaughtering each other without the rest of the world paying much attention. The two parties have aimed their aggression exclusively at each other, and there is no danger of the conflict spreading." ${ }^{\prime 31}$ This proved to be a tragically false, and oddly ahistorical, analysis of the situation.

The violence in Rwanda was seen as the latest episode in a constant of violence that had been going on for decades, and this time was no different:

Except from evacuating foreigners there doesn't seem to be much the outside world can do. No one is ready to accept the humanitarian and moral challenge in preventing the two tribes from yet again opting for mass extermination instead of dialogue. But we know that the combination of inherited hatred and a large population on a small territory makes the rows between Hutus and Tutsis especially gruesome. The next round will not be an exception. ${ }^{32}$

This observation was printed on April $9^{\text {th }}$, at the very beginning of the genocide. The violence is described as cyclic, gruesome but also called a "row", which is a description of children fighting rather than systematic political violence.

The perpetrators were driven by "wild rage" and a "thirst for revenge." 33 They did not act rationally and had nothing to gain politically from the genocide: "The conflict has no ideological

28 "Africa's Killing Fields." Aftenposten, 25 May 1994. Available from: https://web.retriever-info.com/services/archive/displa yDocument?documentId=020002199405250077\&serviceId=2 (accessed May 2010).

29 "Sannesmoen returned home from Rwanda yesterday: - In constant fear for my life." Aftenposten, 15 April 1994. Available from: https://web.retriever-info.com/services/archive/displayDocument?documentId=020002199404150093\&serviceId=2 (accessed May 2010).

30 "Rwanda's Slaughter." Aftenposten, 9 May 1994. Available from: https://web.retriever-info.com/services/archive/displayDo cument?documentId=020002199405090091\&serviceId=2 (accessed May 2010).

31 "Behind the News: Vicious Cycle of Revenge." Aftenposten, 9 April 1994. Available from: https://web.retriever-info.com/ services/archive/displayDocument?documentId=020002199404090050\&serviceId=2 (accessed May 2010).

32 "Behind the News".

33 "11 UN soldiers executed." Verdens Gang (VG), 8 April1994. Available from: https://web.retriever-info.com/services/ archive/displayDocument?documentId=055016199404085852801\&serviceId=2 (accessed May 2010). 
overtones. No larger strategic or economic interests are at risk." 34 The framing of the Rwandan genocide was purely cultural, and the political context was not only under-communicated, it was virtually non-existent.

\section{The Balkans}

The Balkan Peninsula has long served as an inspiration to the Western imagination, ${ }^{35}$ an exotic and mythical part of Europe that was still conveniently close, supposedly slightly dangerous, charmingly old-fashioned and inhabited by people with strange costumes and temperament that, according to the Norsk Telegrambyrå (NTB) in May 1992 left "the outside world shaking their heads over the insanity." Still "no one [was] able to follow through on the demands that these triggerhappy men come to their senses." 36

Like the Rwandans, the people of the former Yugoslavia were repeatedly referred to as triggerhappy and warrior-like. Perceived local customs and temperament were frequently used as an explanation for the violence and as a reason why intervention would be useless. Like in Rwanda, violence was seen as an integral part of the region: "When Yugoslavia's numerous peoples are at each other's throats, this unfortunately happens according to local tradition, following their unappeasable Balkan recipe." ${ }^{37}$

\section{Prisoners of History}

The othering of Rwanda and the Balkans through history framing highlights both their lack of civilization and our possession of it. Patterson argues that

[w] hereas civilization consists of the refined institutions, moral values, and cultures of states and their elites, nature is the essential (natural) condition from which they emerged and to which they are therefore opposed. Uncivilized peoples represent the primary (primitive) or unrefined stages of the human condition which, depending on how the civilized (ruling) classes portray their own history, they either avoided altogether or passed through at an earlier time. ${ }^{38}$

This observation is useful for analyzing history framing. Both Rwanda and Bosnia are seen as stuck in the past, still suffering a fate that we, the civilized, have long left behind.

In the coverage of Bosnia and to a slightly lesser degree Rwanda, history itself was seen as an actor. The peoples of the former Yugoslavia were all "[p]risoners of history" 39 and the history of the area was used as causal precedent for the 1992-95 violence. During the Second World War the Ustaše were purging Serbs, and "[t]his time it's the Serbs who practice 'ethnic cleansing'." ${ }^{40}$ This image of a historically founded "vicious cycle, impossible to break" ${ }^{41}$ contributed to the creation of a narrative of continuation, that the violence in Bosnia in 1992 was a continuum of previous violence - the latest chapter in a long history of violence.

In almost all instances where journalists attempt to give the reader a historic background for the war, history as context is turned into history as fate. If it happened once, it must happen again.

\footnotetext{
34 "Behind the News".

${ }^{35}$ Hansen, Lene. 1997. Western Villains or Balkan Barbarism? Representations and Responsibilities in the Debate over Bosnia. Copenhagen: Institute of Political Science, University of Copenhagen, Anzulovic, Branimir. 1999. Heavenly Serbia: From Myth to Genocide. New York: New York University Press, and Todorova, "From Discovery to Invention".

36 "Failure in the Balkans." Norsk Telegrambyrå (NTB), 6 May 1992. Available from: https://web.retriever-info.com/services/ archive/displayDocument?documentId=055013199205060641\&serviceId=2 (accessed May 2010).

37 "Deadly Freedom." Aftenposten, 25 August 1992. Available from: https://web.retriever-info.com/services/archive/display Document?documentId=020002199208250041\&serviceId=2 (accessed May 2010).

${ }^{38}$ Patterson, Western Civilization, 21.

39 "Prisoners of History." Aftenposten, 6 September1992. Available from: https://web.retriever-info.com/services/archive/dis playDocument?documentId=020002199209060049\&serviceId=2 (accessed May 2010).

40 "Serbs with Nazi-like discrimination." NTB, 29 August 1992. Available from: https://web.retriever-info.com/services/ archive/displayDocument?documentId=055013199208293658\&serviceId=2 (accessed May 2010).

41 "A Cleansed Serb Town." NTB, 20 August 1992. Available from: https://web.retriever-info.com/services/archive/displayD ocument?documentId=055013199208202482\&serviceId=2 (accessed May 2010).
} 
In this understanding, history is not created by people; people (some more than others) are simply unwitting pawns in a predetermined history/fate-"Just like in Croatia the current events are dictated by historical differences. And now new hatred is sown that will plague people in decades to come." 42 The idea that the current (and future) political situation was dictated by the past reveals a view of history not as the sum of political decisions but as a force in and of itself.

The violence is viewed through a fatalistic lens and makes it possible for the observer to condemn what is happening without having any realistic belief that it could be stopped, that we would have to do anything. "In a continuation of the Second World War neighbours are killing each other in blind acts of revenge." ${ }^{43}$ Because something was it must also be and cannot be stopped. Once history is introduced as an explanation, the conflict and the violence are seen as not only unstoppable, but in fact necessary. The war and so-called ethnic cleansing are unequivocally condemned, but at the same time perceived as natural and framed as an evil that could purge the population of their demons.

This view was expressed even more explicitly when talking about Rwanda; only a week into the genocide, journalists were already reporting "...There is no hope to stop this now. They are going to slaughter each other, and only after a bloody showdown might they be able to start over."44

Both the Rwandans and the people of the former Yugoslavia were bound by their place of birth and by history. In over-accentuating distance not only through geography, but also through history, the events were de-realized on multiple levels. By framing the events as history-driven they became part of a narrative of inevitability. This narrative was also accompanied by the denial of the victim where the inability to comprehend victimization (whether because of sheer numbers, or primordial hatreds) becomes paralytic; we are resigned to inaction in the face of grave, essential, and eternal evil. Intervention in such situations is not a meaningful possibility. To intervene would mean to place oneself in the midst of an incomprehensible and insurmountable bloodletting. We may feel empathy for the victims but it is an empathy grounded in distance, more akin to sympathy. The danger and incomprehensibility of the violence, as presented in the media, has removed all notions of our own moral agency.

\section{Media Narratives and the Will to Intervene}

The Responsibility to Protect

The mass atrocities in Rwanda and Bosnia occurred before the crystallization of the responsibility to protect principle. In fact, the principle itself emerged partly in response to the international community's failure to act in these catastrophic cases. Nonetheless the principle provides an interesting normative lens through which to view the obligation to intervene and the neutralization of this obligation.

The concept of the Responsibility to Protect (R2P) originated with the 2001 report of the International Commission on Intervention and State Sovereignty (ICISS), a commission of experts tasked with determining appropriate policy responses to situations of mass atrocities such as Rwanda and Srebrenica. The report determined that humanitarian intervention was justifiable under the following circumstances:

....there must be serious and irreparable harm occurring to human beings, or imminently likely to occur, of the following kind:

A. large-scale loss of life, actual or apprehended, with genocidal intent or not, which is the product either of deliberate state action, or state neglect or inability to act, or a failed state situation; or

\footnotetext{
42 "Bosnia is New Croatia." Aftenposten, 11 April 1992. Available from: https://web.retriever-info.com/services/archive/displa yDocument?documentId=020002199204110027\&serviceId=2 (accessed May 2010).

43 "Failure in the Balkans." NTB, 6 May 1992. Available from: https://web.retriever-info.com/services/archive/displayDocu ment? documentId=055013199205060641\&serviceId=2 (accessed May 2010).

44 "Now the slaughter begins for real." NTB, 13 April 1994. Available from: https://web.retriever-info.com/services/archive/ displayDocument?documentId=055013199404131342\&serviceId=2 (accessed May 2010).
} 
B. large-scale 'ethnic cleansing', actual or apprehended, whether carried out by killing, forced expulsion, acts of terror or rape. ${ }^{45}$

In addition to this "just cause" threshold the report also required that intervention should only occur under the "right authority." ${ }^{46}$ Furthermore, the commission embraced the following precautionary principles: intervention should only occur with the right intention and as a last resort, and it should be proportional with reasonable prospects of success. ${ }^{47}$ It is important to note that the Responsibility to Protect doctrine went beyond military intervention to include a range of policy responses under the categories "the responsibility to prevent," the "responsibility to react," and "the responsibility to rebuild." The concept of R2P was subsequently enshrined as a UN policy in the 2005 Outcome Document of the UN Millennium Summit. ${ }^{48}$ R2P is now widely cited as a guiding framework in determinations of whether to intervene in response to mass atrocities; a kind of globalized Good Samaritan principle.

In spite of the emergence of the doctrine there is still significant debate among bystander states as to when to intervene in response to mass atrocities. The existing framework for the invocation of the responsibility to protect is comprised of general, unarticulated criteria. When making decisions to intervene, policy makers always apply subjective and situational lenses to their interpretation of events and resultant normative and legal obligations for intervention. This interpretive process is applied to available and influential information. Media narratives help to shape public discourse, which in turn shapes our way of thinking and speaking about mass atrocities. Policy-makers may be directly influenced by such discourse but also act partly in response to popular perceptions and public pressure. The media, it would seem, contribute to the formation of political constituencies for the responsibility to protect.

The Role of the Media in Public Policy Debates

The media may play an important role in communicating information and encouraging, or discouraging, humanitarian action. They mediate between those in zones of safety and zones of suffering. ${ }^{49}$ Subjectivity is embedded in every aspect of the process of reporting. Reporters seek to present facts but also to make these facts comprehensible and meaningful to their intended audience. This process entails the selection of facts, characterization of facts, and interpretation of factual information. This subjective analysis may occur on both sub-conscious and conscious levels. Reporters may, at times, intentionally select and present facts in a certain light in order to achieve political ends, such as encouraging humanitarian intervention. For example, Pullitzer Prize winning reporter Roy Gutman said that he consciously chose to emphasize the commission of atrocities in the Bosnian civil war in order to draw attention to this humanitarian catastrophe..$^{50}$

It is the media which present such stories to ordinary citizens and policy-makers alike. These policy-makers make decisions on the basis of a situation-specific constellation of personal and institutional factors. Thus, their decisions are based on both individual and collective political interests and personal inclinations. The Responsibility to Protect provides a normative framework for bystander states with regards to responses to mass atrocities.

However, the influence of the mass media on foreign-policy making is hotly contested. There are several possible effects of the media on the formulation of foreign policy. The media may bring an issue to the attention of policy-makers. In the event that there is substantial policy uncertainty the media may put significant pressure on policy makers to swiftly develop a policy in response to a

\footnotetext{
${ }^{45}$ International Commission on Intervention and State Sovereignty (ICISS). 2001. "Final Report - The Responsibility to Protect." Ottawa: International Development Research Centre, xii.

${ }^{46}$ The United Nations Security Council, or, if action is not authorized in a timely manner the UN General Assembly, or sub-regional or regional organizations acting pursuant to Chapter VII of the UN Charter, with the caveat that they must subsequently seek authorization from the UN Security Council.ICISS XII-XIII.

${ }^{47}$ ICISS XII.

${ }^{48}$ UN World Summit Outcome Document. G.A. Res. A/Res/60/1, Oct. 24 2005, paras. 138-140.

${ }^{49}$ Ignatieff, Michael. 1997. The Warrior's Honor: Ethnic War and the Modern Conscience. New York: Henry Holt \& Company.

${ }^{50}$ Personal communication between Kjell Anderson and Roy Gutman, Stockholm, Sweden, 15 November, 2013.
} 
critical issue. ${ }^{51}$ This agenda-setting effect of media appears to be particularly strong..$^{52}$ For example, former Canadian National Defence Minister David Collenette argues that he was unaware of the Rwandan genocide until the spread of "horrific press reports." Oulette recalls, "We didn't know. It was not something that was in the papers. Therefore, the public didn't know, and therefore, the politicians didn't talk about it or didn't look at it as an urgent priority." ${ }^{53}$

The media may not dictate what people should think, but it does tell people what to think about. The attention that the media pays to a particular issue may result in the de facto ranking of foreign policy issues on the basis of their perceived saliency ${ }^{54}$ Moreover, media effects are strongest on issues of which the public might not otherwise be aware..$^{55}$

This agenda-setting effect may be so strong that policy-makers simply refuse to address an issue until it has been discussed in the media. Human Rights Watch's Allison Des Forges recalls a meeting with US National Security Advisor Anthony Lake during the Rwandan Genocide, "He just said, 'Make more noise. We listen to noise'." Des Forges rejected this justification arguing that "It's a cheap excuse. It's basically saying force us to do it because we're not going to take the political risks involved to do the right thing on our own." ${ }^{56}$

The media may also help to create constituencies for humanitarian intervention by galvanizing public support. ${ }^{57}$ The presence of strong support for humanitarian intervention does not often force policy-makers into intervening, rather it enables that intervention by showing it to be politically acceptable. Moreover, the so-called $\mathrm{CNN}$ effect might prove to be weak in cases of high-risk interventions involving ground troops. ${ }^{58}$

Finally, as we have argued, the media may "frame" the debate through narratives. Framing is a matter of defining the ways in which we speak about a certain policy debate. Livingston argues that in many cases the media merely echoes and reinforces government policy positions. ${ }^{59} \mathrm{We}$ cannot claim here to offer any definitive answers as to the impact of mass media on public policy, rather, we simply argue that media discourses may echo and reinforce existing narratives that facilitate passivity among bystanders. In our subsequent analysis we will be focusing on how the media discourses outlined thus far shape the decision of bystanders to intervene in response to mass atrocities.

\section{The Media and Political Will}

Proponents of the responsibility to protect doctrine often argue that politicians lack the political will to intervene in defence of others. ${ }^{60}$ This political will entails the willingness to take politically risky decisions in furtherance of normative principles and indirect interests. Such decisions offer the prospect of scant personal or collective gain and substantial risk. The source of political will is, arguably, partly personal and partly contextual. The framing of atrocities often serves to reinforce existing cultural myths and stereotypes, further distancing victims and emphasizing the risks of intervention and the acceptability of non-intervention.

\footnotetext{
${ }^{51}$ Robinson Piers. 2002. The CNN-effect. The Myth of News, Foreign Policy and Intervention. London: Routledge, 32. See also Panagioutou, Nikos. 2005. “The Role of Mass Media in Public Policy: The Case of the Greek Press," paper for $2^{\text {nd }}$ London School of Economics PhD Symposium on Modern Greece, June 10.

${ }^{52}$ McCombs, Maxwell E. and Donald L. Shaw. 1972. "The Agenda-Setting Function of the Mass Media." Public Opinion Quarterly, Vol. 36, No. 2, 176-185.

${ }^{53}$ Dallaire et al, "Will to Intervene", 73.

${ }^{54}$ Soroka, Stuart N. 2002. "Issue Attributes and Agenda-Setting by Media, the Public, and Policy-Makers in Canada." International Journal of Public Opinion Research Vol. 14, No. 3, 266.

${ }^{55}$ Soroka, "Agenda-Setting," 269.

${ }^{56}$ Dallaire et al, "Will to Intervene," 98.

${ }^{57}$ Robinson, CNN-effect, 40.

${ }^{58} \mathrm{Ibid}, 126$.

${ }^{59}$ Steven Livingston. 1997. "Clarifying the CNN Effect: An Examination of Media Effects According to Type of Military Intervention." (Research Paper R-18) Cambridge, MA: The Joan Shorenstein Center, John F. Kennedy School of Government, Harvard University. See also Sidahmed et al, The Responsibility to Protect in Darfur, 47-48.

${ }^{60}$ See, for example Dallaire et al, "Will to Intervene".
} 
Media effects on policy-makers may be particularly strong in cases of policy uncertainty ${ }^{61}$ In the case of third-party bystanders to mass atrocities, political will often seems to require that sufficient levels of outrage be generated so as to make the defence of others compelling. ${ }^{62}$ Interestingly, political scientist Barbara Harff found that the magnitude of atrocities, and appropriate level of empathy, are dictated less by the number of people victimized and more by the nature of the victimization itself (i.e. if the violence is especially gruesome or evocative). ${ }^{63}$ Nonetheless, we would argue that saliency of mass atrocities is not determined by accounts of extreme violence; rather these accounts can actually function as distance-framing (the denial of the victim). When violence reaches a certain level of extremity it may actually become abstract.

Political will, in the sense of the will to defend others, differs from the will of individual bystanders to intervene in that political decision-makers act within larger decision-making structures, which may themselves be prone to caution and inertia. The institutionalization of decision-making itself greatly slows down response times.

Neville Chamberlain was famously dismissive of the prospects of British intervention in response to Nazi German expansionism, arguing that it was "a quarrel in a faraway country between people of whom we know nothing." ${ }^{44}$ How can political will be mobilized to intervene in defence of others? Gareth Evans argues that the creation of such political will involves: ensuring knowledge, encouraging concern, building confidence, leadership, and creating appropriate institutional processes to implement effective responses. ${ }^{65}$

Let us examine each of these factors in turn, as they relate to bystander neutralization and media narratives. In the age of globalization, no one can claim a lack of knowledge as an excuse for not responding to mass atrocities; indeed, in a sense, we are all distant bystanders to atrocities occurring on the other side of the world. Of course media accounts of such situations are often lacking in depth and sustained engagement. Moreover, such accounts often revel in a kind of historical determinism which is distinctly ahistorical. Discourses of exoticism (the claim of ignorance) impede policymakers' ability to comprehend a given situation. Therefore, policy-makers cannot rely solely on media accounts of mass atrocities. Moreover, knowledgeable observers, such as non-government organizations and scholars, must provide information to policy makers in a succinct and impactful manner. Knowledge, where it is grounded in cultural myth, may also mislead decision-makers as political conflicts come to be understood as tribal eruptions.

In the aftermath of the Rwandan genocide Bill Clinton explained the international community's non-intervention: "All over the world there were people like me sitting in offices day after day, who did not fully appreciate the depth and the speed with which you were being engulfed in this unimaginable terror." ${ }^{66}$ Yet American policy-makers were in fact aware of much of what was happening in Rwanda and instead exhibited a kind of willful blindness towards the humanitarian crisis. This is evinced by their determined effort to avoid the use of the term genocide. Similarly, in the case of Bosnia, it was simply not true that bystanders did "not know" or "appreciate" the violence unfolding, rather they retreated to the "twilight between knowing and not knowing." 67 Thus, knowledge is not only about the mere availability of information, but also the saliency of this information. In many circumstances it is simply implausible for bystanders to claim ignorance.

This brings us to the second prerequisite for the development of political will: ensuring concern. The level of empathy that bystanders feel towards the victims of mass atrocities may influence their decision to intervene (although this is also mediated by other factors). If bystanders feel a kinship with the victim they are more likely to intervene. This is borne out by the research

\footnotetext{
${ }^{61}$ Robinson, CNN-effect, 118.

${ }^{62}$ See Anderson, Kjell. 2013. “Syria and Serendipity of Outrage," blog post for The Hague Institute for Global Justice. Available from: http://goo.gl/MNvGzM, published on 4 September (accessed on 10 July 2014).

${ }^{63}$ Harff, Barbara. 1987. "Empathy for Victims of Massive Human Rights Violations and Support for Government Intervention: A Comparative Study of American and Australian Attitudes." Political Psychology Vol. 8, No. 1, 8.

${ }^{64}$ Evans, Gareth. 2008. The Responsibility to Protect. Washington, D.C.: Brookings Institution, 229.

${ }^{65} \mathrm{Ibid}, 223-243$.

${ }^{66} \mathrm{Ibid}, 225$.

${ }^{67}$ Power, Problem from Hell, 506.
} 
on individual bystanders to genocide, which shows that perpetrators sometimes rescue people known to them personally ${ }^{68}$ Positive intimate relationships enable perpetrators to break through the abstraction of victims - they are once again individuated and personalized.

Distant Bystanders may also abstract victims of mass atrocities, particularly when these victims are geographically and culturally remote (as victims in Bosnia and, especially, Rwanda were perceived). In such situations the norm of reciprocity, found in so many religious and cultural traditions, may not seem to apply. What interest is there in the protection of others when it is highly unlikely that these others will ever have the opportunity or motivation to act in protection of you? In the West, with its power and its privilege, the defence of others can rightfully be seen as a one-way proposition. This asymmetry of needs is often reflected in discourses that bemoan the seeming perpetual conflict and poverty of Africa.

The urgency of the plight of actual and potential victims is another aspect of ensuring concern. Are these victims in immediate physical jeopardy or is their problem more akin to a long-term state of physical insecurity or political and economic marginalization? In situations where the dangers faced by victims are more immediate, one would expect the urgency to intervene would be more acute. Yet, one could also posit that where the destruction of the victims is seen as inexorable or already accomplished, the urgency to intervene may also be lesser. Why expose oneself to risks where it is already too late to save the victims? In Rwanda and Bosnia media accounts were often so fatalistic that the death of the victims seemed a foregone conclusion.

Much as perpetration is eased by the diffusion of responsibility in crowds, bystander apathy is also facilitated by a lack of individual accountability for the decision not to intervene. If the bystander is the only person capable of assisting the victim, then the likelihood of intervention greatly increases.$^{69}$ In such situations individuals become personally responsible for their failure to ease the suffering of the victim. Bystanders will take their cues from other bystanders and a type of 'conspiracy of blindness' may settle in where a group of individuals wordlessly collude in ignoring the plight of a victim.

In order to encourage concern among policy-makers within states, you must also sometimes go beyond normative principles and humanitarian concerns to demonstrate that intervention is in the national interest. This entails the evolution of the concept of national security beyond state borders, and even beyond the normative concerns of human security doctrine, to consider global security. ${ }^{70}$ We must remember that mass atrocities are global traumas generating instability, refugee flows, environmental destruction, poverty, and further violence. Responding to mass atrocities, even in distant countries, is often in the national interest.

The media plays a crucial role in encouraging concern through its agenda-setting function. Roméo Dallaire notes that media coverage in Rwanda wasn't extensive until a month and a half into the genocide, and this increased media coverage may have contributed to the UN Security Council's decision to approve a mandate for UNAMIR II on May 17: "I think it was wear and tear by media, the continuing of the genocide, and the realization that this goddamn thing wasn't ending." ${ }^{\prime 11}$

Would-be interveners must also be confident that intervention will bring about a desirable and intended result. If they lack the adequate material or emotional means (in the case of individuals) to interdict victimization, then they may decide that intervention is not worth the risk or effort. In the collective context states often seem to be reluctant to act in isolation, as acting in isolation may expose them to additional normative and material risks.

The risks of intervention will also be considered under the aegis of building confidence. Does intervention entail the loss of security, material goods, or prestige? Individual assistance to victims of state-directed mass atrocities will often occur covertly. States might also consider the effects of intervention (or non-intervention) on their bilateral and multilateral relations. The likelihood

\footnotetext{
${ }^{68}$ Munroe, Kristin Renwick. 2004. The Hand of Compassion: Portraits of Moral Choice During the Holocaust. Princeton: Princeton University Press, 214.

${ }^{69}$ Staub, Psychology, 73.

${ }^{70}$ Dallaire et al, "Will to Intervene," 4.

${ }^{71} \mathrm{Ibid}, 101$.
} 
of intervention decreases where material and physical costs are high. ${ }^{72}$ Effort is another, closely related, determinant of the likelihood of individual or collective intervention to protect victims of mass atrocities. In situations where the victim(s) can be assisted with minimal effort, the likelihood of intervention should increase.

Media discourses emphasizing place, in particular the jeopardy associated with the state where intervention is to take place, arguably reduce confidence in the potential for successful intervention. In general, the de-politicization of political violence which often occurs in popular perceptions of mass atrocities renders violence incomprehensible, precluding consideration of successful intervention.

Beyond these factors political will also requires effective processes. Paradoxically, individuals and states that may be too weak to effect results individually may be able to do so collectively. Intervention to prevent or stop violence often requires the courage to act alone, although, in the global context, acting alone may be of questionable legality. The only decision-making body in the world with the authority to authorize the use of force in circumstances other than individual or collective self-defence is the United Nations Security Council. Even in the absence of UN Security Council authorization, states may still seek to construct a "coalition of the willing" to diffuse the political and military risks of independent action.

Finally, leadership also plays an essential role. Leaders who do not consider intervention essential will inevitably fail to act. The media can play a critical role here in ensuring that political costs of inaction are higher than the costs of action. They accomplish this, not so much through advancing an activist agenda, or encouraging empathy, but rather through accurate reportage which encourages substantial engagement with the problem of mass atrocities. Individual and collective interests also play a role-bystanders may consider whether it is in their best interests to act. Will intervention bring material or emotional rewards? Will individuals gain or lose prestige through intervention? In the state context, prestige and political capital may be of particular relevance to political leaders while they may also consider the general material interests of the state.

Mass media and cultural narratives may play an important role in neutralizing the obligation for bystanders to intervene. The media shapes the discourse by framing the debate around the responsibility to protect and humanitarian intervention. As we have already illustrated, the way in which journalists frame the discourse may provide bystanders with ready justifications for nonintervention; justifications which themselves may be a mere shield for self-interested isolationism in contradiction to the universalist notions of reciprocity which are fundamental to human rights discourse. Indeed, as Alex Bellamy argues, the ambiguity of the concept of R2P may in fact reduce its "compliance pull." ${ }^{73}$

Many of the discourses found in the media reinforce the bystander techniques of neutralization and the factors which discourage intervention. It is interesting to note that the Responsibility to Protect doctrine was never mentioned explicitly in the New York Times or in major American broadcast outlets during the entire duration of the crisis in Darfur. ${ }^{74}$ It is our contention, however, that the exclusion of explicit mention of the responsibility to protect or calls for humanitarian intervention is less important than the media's tendency to craft a discourse discouraging active policy responses to mass atrocities.

In some sense, the bystander techniques of neutralization, and media narrative framing, are facilitated by the ambiguities inherent in the R2P framework. In the absence of clarity, many bystanders will be reluctant to intervene. ${ }^{75}$ Unfortunately, modern situations of mass atrocities are often lacking such clarity. When two sides are armed and committing atrocities, as is the case in Syria, who are the victims? Under the precautionary principle of "right intention," the ICISS report

\footnotetext{
${ }^{72}$ Staub, Psychology, 76.

${ }^{73}$ Bellamy, Alex J. 2010. “The Responsibility to Protect - Five Years On.” Ethics and International Affairs Vol. 24, No. 2, 161.

${ }^{74}$ Sidahmed et al, editors, To Protect, 102.

${ }^{75}$ Staub, Psychology, 79.
} 
requires that military intervention must be clearly supported by the victims. ${ }^{76}$ Such a construction presupposes that victimization will be entirely asymmetrical. In reality, would-be interveners may lack clarity over the identity of the victims or the legality of their intervention. ${ }^{77}$

Moreover, R2P calls for the intervention only in cases where there are "reasonable grounds for believing lesser measures would not have succeeded." ${ }^{\prime 7}$ What are these reasonable grounds, and how does such a calculation relate to the claim of jeopardy where bystanders argue deliberately that to intervene would be too dangerous as a means of avoiding a responsibility to intervene? Is the success of the overall mission measured in its result? Is there a level of casualties on the side of the intervening state(s) which is so great that the mission is considered to be unsuccessful, even if it achieved its objective? Assessments of risk may be derived from tactical assessments, but these assessments may also be interpreted through cultural understandings produced (and reproduced) in the mass media. Perceived jeopardy may increase significantly if, once intervention has begun, the media broadcasts images of casualties among the intervening country's forces. ${ }^{79}$

One might ask whether states (and even individuals) gain more benefit from seeming moral than from being moral? Bystanders have multiple action alternatives when facing situations of victimization. They may intervene to assist the victim, or, alternatively, they may contribute to the victimization. They may also choose to be willfully blind, ignoring the victimization or they may even leave the location of victimization so as to avoid empathetic distress. Finally, they may posture, performing minimal acts to assist the victim yet avoiding substantial engagement. This kind of moral posturing has the benefit of allowing bystanders to maintain their self-image as moral beings, acting in assistance to victims, while still avoiding the risks that come with more substantial forms of engagement. Moral behavior is not always altruistic-rather it can, at times, be purely selfish and instrumental.

Moral posturing seems to be especially prevalent in the sphere of international relations. States may express outrage, passing resolution after resolution demanding compliance with international law yet fail to take any action to change the situation on the ground. Alternatively, they may reframe mass atrocities as a "humanitarian crisis." Viewing atrocities through such a lens removes the culpability of the perpetrators and the necessity for bystanders to "choose sides" or take military action. Through such acts they can maintain their role, and their self-image, as being defenders of the downtrodden without engendering any substantial risks. This is particularly true when states are geographically distant and not faced with the direct fallout of mass atrocities such as mass refugee movements. The media, through its discourses of inevitability, may even contribute to moral posturing by focusing less on meaningful policy responses and more on the unfathomable nature of the violence itself.

Some states, and some individual bystanders, may even benefit from the victimization of others through, for example, the weakening of their rivals or the appreciation of their reputation relative to the outrages committed by their peers. Of course, states and individuals may also act as profiteers in times of mass atrocities, taking advantage of instability and the absence of a strong state in order to exploit the country where violence is taking place, or to directly profit through selling the means of violence to the antagonists or perpetrators.

Not all states or individuals are equally equipped to intervene in response to mass atrocities. This reality was reflected in the Bosnia v. Serbia case at the International Court of Justice where the court found that the responsibility to prevent genocide is a differential responsibility. ${ }^{80}$ In other words, states with a greater capacity to prevent mass atrocities, in a given state, also bear a greater moral and legal responsibility for the failure to prevent. This responsibility is objective, existing

\footnotetext{
${ }^{76}$ ICISS, The Responsibility to Protect, xii.

${ }^{77}$ Such doubts as to the legality of their intervention will also decrease their likelihood of intervention. In experiments Staub showed that individuals who were presented with a situation of a person in distress in another room were less likely to aid the person in distress if they believed they lacked permission to enter the room. See Staub, Psychology, 84 .

${ }^{78}$ ICISS, The Responsibility to Protect, xii.

${ }^{79}$ Robinson, CNN-effect, 39.

${ }^{80}$ Application of the Convention on the Prevention and Punishment of the Crime of Genocide (Bosnia and Herzegovina v. Serbia and Montenegro). Judgment, I.C.J. Reports 1996, 595.
} 
irrespective of any subjective rationalizations seeking to minimize or void the responsibility to protect.

One could even argue that the Responsibility to Protect engenders a specific legal obligation to intervene militarily in response to genocide, crimes against humanity, and other mass atrocities. Yet, current practice is far too inconsistent to really evince the crystallization of a legal norm beyond a normative pledge. One might ask what level of specific involvement in the conflict prevention and resolution in other countries is required in order to fulfill one's responsibility to protect? Is diplomatic engagement enough? Is referral to the International Criminal Court sufficient? Or are these mere forms of moral posturing?

One of the central dilemmas with regards to the responsibility to protect is our seeming inability to universalize victims. Not all victims seem to be created equal. Situations of apparent ambiguity and symmetry between antagonists do not lend themselves to engendering the outrage required for bystander intervention. We seek out stark contrast - good and evil, right and wrongand to apply these dichotomies to actors with complex means and motives. Situations such as the civil war in Syria, where multiple belligerents commit atrocities and use violence to advance their interests, seem to be the antithesis of the vision of victimization arising out of the Holocaust, a vision which has defined the international human rights discourse and movement.

In reality, both Rwanda and Bosnia were simultaneously armed conflicts and genocides; this seems to have the effect of muddying interventionist discourse and increasing resistance to intervention. In situations where victims do not belong solely to a single side and where they are not completely disempowered, then the responsibility to protect does not seem to apply. Of course, such an interpretation does not flow from the normative definitions of the principle itself but rather from our subjective interpretations of its invocation.

Bystander techniques of neutralization, in the form of media discourses, may have the effect of eroding the political will to intervene pursuant to the responsibility to protect doctrine. They increase impressions of jeopardy, ambiguity, and victim culpability, among other things, creating a scenario where the obligation to intervene becomes increasingly treacherous, unnecessary, or even unjust. The question of causation remains uncertain in our hypothesis - the media is not always a producer of knowledge-but rather it often reproduces common understandings. It is also reliant on the government as a source of information, and arguably, for normative framing. This relationship is undoubtedly interactive as the media both produces and consumes narratives found in popular perceptions and decision-making institutions. At any rate we believe that media discourses reinforce the narratives and processes which undermine the will to intervene. If political will is partly comprised of a personal and institutional weighing of risks and benefits then reporting which emphasizes risks (both concrete and metaphysical) and cultural biases that preclude deeper engagement will erode this will.

\section{Conclusion}

Genocide and crimes against humanity are crimes committed by individuals with criminal intent. They are not metaphysical phenomena driven by historical determinism, whereby tribal groups come to inevitable, fatal blows. Violence, as seen through the media, is de-politicized and dramatized. Indeed, there is a powerful fatalism which underlies much of the reporting that emerged out of the Bosnian and Rwandan genocides where 'genocide was bound to happen, and now that it is here, it is unstoppable.'

The victims themselves are cast as lambs to the slaughter; they are noble in their victimhood, suffering in silence, devoid of agency. This ennobling martyrdom of victims brings fatal effectvictimhood is their fate and their lot. In Bosnia, it was said that "Europe is dying," 81 yet in reality Europe is another abstraction, albeit a geopolitical one, and the only death that was real was the death of individual victims.

This narrative of failure began early in Rwanda, right from the beginning of the genocide. The media focused more on the inevitability of the West doing nothing than the possibility of the West

\footnotetext{
81 "Are We Letting Europe Die in Sarajevo?" Aftenposten, 17 September 1993. Available from: https://web.retriever-info.com/ services/archive/search (accessed May 2010).
} 
acting. The actual perpetrators of violence in Rwanda were often obscured by this cosmopolitan navel-gazing, which cast the West as the real, immutable perpetrator.

Guilt itself can function as an engine of apathy. Without effective policy responses guilt is just another form of paralysis. There is a certain self-gratifying sorrow which appears to represent empathy for the victims, all the while precluding intervention to bring about the end of victimization. Our fact of inaction may be eased by our resultant, apparent emotional distress.

The effect of this disempowering media discourse may be profound. Genocide prevention is no longer a policy question. We are witnesses to history rather than its authors. With the advent of the Responsibility to Protect doctrine, such inaction should be a thing of the past; and yet, in Syria, the Central African Republic and South Sudan, atrocities continue to be cast as inevitable tragedies without evoking a need for practical, policy responses.

We can question whether the obligation to intervene is actually present, and if so, is this obligation more about seeming moral than taking constructive action? It is beyond our scope here to offer definitive answers to these queries but we maintain that media narratives, in certain forms, may make it easier for bystanders to abstain from constructive action to end violence. Suffering, in fact, is not ignored but rather reconstituted as something outside of our power to effect.

Media discourses often render victim worlds as remote. Yet, perhaps the media does not drive this bystander apathy, but is rather reflective of it. We must ask ourselves whether we really want to relate with the plight of victims. Or is such empathy even possible? Do we want to visit victim worlds, or do they challenge our very metaphysical security? For people living in relative comfort, suffering on an extreme level may be completely incomprehensible. What are our responsibilities towards those whose suffering we cannot comprehend?

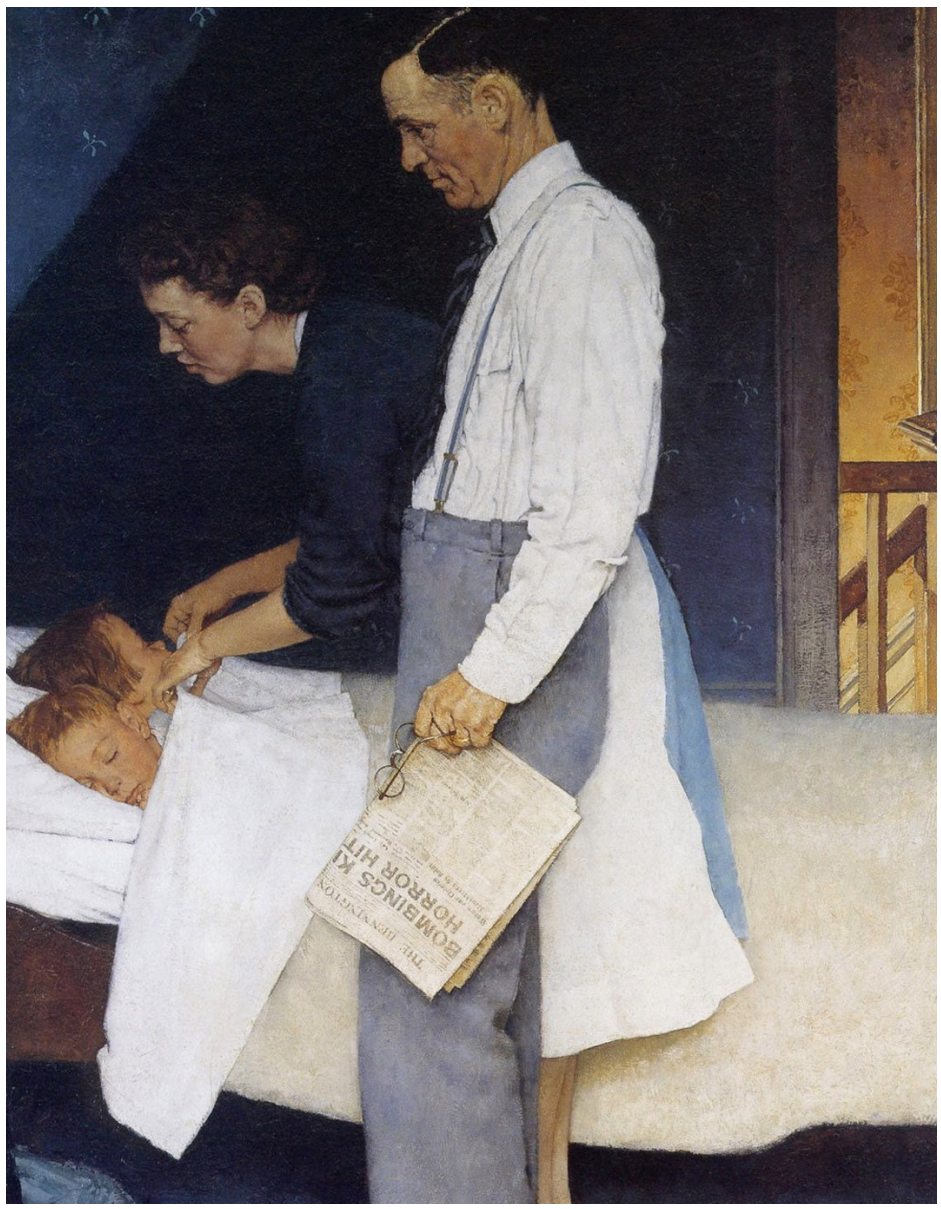

Figure 2. Freedom from Fear (Painting), Norman Rockwell. Source: Norman Rockwell Museum via Wikipedia https://en.wikipedia.org/wiki/Freedom from Fear (painting)\#/media/File:Freedom from Fear.jpg. 
This desire to remain firmly rooted in zones of safety with an "appropriate" distance from danger, and ignorance to its effects, is well represented by the Norman Rockwell painting Freedom from Fear. In the painting a father is tucking his children into bed while clutching a newspaper in his hand. Above the fold the words "bombing" and "horror" are clearly visible. This artwork is intended to illustrate the universal right to be free from fear. However, what it actually tells us is that freedom from fear is not a matter of universal safety, but rather the right to be insulated from the suffering of others in distant and foreign lands. Distance and futility framing create a security blanket that allows us, distant bystanders, to watch and sympathize from a safe distance. We can only engage with distant suffering in superficial ways when it is perceived as inevitable, alien, and outside of our control.

In Rockwell's painting the media does not bring the world closer, but rather atrocities only echo distantly on the newspaper pages we hold as we go about our daily routine. The world remains a vast place, where suffering is bounded by geography.

\section{Bibliography}

Allan, Stuart and Zelizer, Barbie, editors. 2004. Reporting War. Journalism in Wartime. London: Routledge.

Anderson, Kjell. 2013. "Syria and the Serendipity of Outrage." Available from: http://goo.gl/ MNvGzM (accessed on 10 July, 2014)..

Anderson, Kjell. 2011. The Dehumanisation Dynamic: A Criminology of Genocide. Doctoral thesis in International Human Rights Law. Galway, Ireland: National University of Ireland.

Anzulovic, Branimir. 1999. Heavenly Serbia. New York: New York University Press.

Bellamy, Alex J. 2010. "The Responsibility to Protect - Five Years On." Ethics and International Affairs Vol. 24, No. 2: pages 143-169. http://dx.doi.org/10.1111/j.1747-7093.2010.00254.x

Breakey, Hugh. 2011. The Responsibility to Protect and the Protection of Civilians in Armed Conflict: Review and Analysis. Brisbane: Institute for Ethics, Governance and Law, Griffith University.

Cushman, Thomas and Stjepan G. Mestrovic, editors. 1996. This Time We Knew. Western Responses to Genocide in Bosnia. New York: New York University Press.

Dallaire, Romeo, Frank Chalk, Kyle Matthews, Carla Barqueiro, and Simon Doyle. 2009. Mobilizing the Will to Intervene: Leadership and Action to Prevent Mass Atrocities. Montréal: Montréal Institute for Genocide Studies, Concordia University.

Evans, Gareth. 2008. The Responsibility to Protect. Washington, D.C.: Brookings Institution.

Fairclough, Norman. 1995. Media Discourse. London: Hodder Education.

Gagnon, Jr., V. P. 2004. The Myth of Ethnic War. Serbia and Croatia in the 1990s. Ithaca: Cornell University Press.

Geertz, Clifford. 1963. Old Societies and New States. New York: Free Press.

Gini, Gianluca, Tiziana Pozzoli, and Kay Bussey. 2015. "The Role of Individual and Collective Moral Disengagement in Peer Aggression and Bystanding: A Multilevel Analysis." Journal of Abnormal Child Psychology. Vol. 43, No. 3: pages 441-452. http://dx.doi.org/10.1007/ s10802-014-9920-7

Goldsworthy, Vesna. 2012. Inventing Ruritania: The Imperialism of the Imagination. Oxford: Oxford University Press.

Gustafsson, Tommy. 2010. "Swedish television News Coverage and the Historical Media Memory of The Rwandan Genocide." Scandia Vol. 76, No. 2: pages 80-98.

Hansen, Lene. 1997. Western Villains or Balkan Barbarism? Representations and Responsibilities in the Debate over Bosnia. Copenhagen: Institute of Political Science, University of Copenhagen.

Harff, Barbara. 1987. "Empathy for Victims of Massive Human Rights Violations and Support for Government Intervention: A Comparative Study of American and Australian Attitudes." Political Psychology Vol. 8, No.1: pages 1-20. http://dx.doi.org/10.2307/3790983

Ignatieff, Michael. 1997. The Warrior's Honor: Ethnic War and the Modern Conscience. New York: Henry Holt \& Company.

International Commission on Intervention and State Sovereignty (ICISS). 2001. "Final Report - The Responsibility to Protect." Ottawa: International Development Research Centre. 
International Court of Justice. 1996. Application of the Convention on the Prevention and Punishment of the Crime of Genocide (Bosnia and Herzegovina v. Serbia and Montenegro). Judgment, I.C.J. Reports.

Kaufman, Stuart J. 2006. "Symbolic Politics or Rational Choice? Testing Theories of Extreme Ethnic Violence." International Security Vol. 30, No. 4: pages 45-86. http://dx.doi.org/10.1162/ isec.2006.30.4.45

Kaufman, Stuart J. 2001. Modern Hatreds. The Symbolic Politics of Ethnic War. Ithaca: Cornell University Press.

Latane, Bibb and John Darley. 1970. The Unresponsive Bystander: Why doesn't he help? New York: Appleton.

Livingston, Steven. 1997. "Clarifying the CNN Effect: An Examination of Media Effects According to Type of Military Intervention." Research Paper R-18. Cambridge, MA: The Joan Shorenstein Center, John F. Kennedy School of Government, Harvard University.

McCombs, M.E. and D.L. Shaw. 1972. "The agenda-setting function of the mass media." Public Opinion Quarterly Vol. 36, No. 2: pages 176-185. http://dx.doi.org/10.1086/267990

Mueller, John. 2000. "The Banality of 'Ethnic War'." International Security Vol. 25, No. 1: 42-70. http://dx.doi.org/10.1162/016228800560381

Munroe, Kristin Renwick. 2004. The Hand of Compassion: Portraits of Moral Choice During The Holocaust. Princeton: Princeton University Press.

Myers, Klak, and Koehl. 1995. "The inscription of difference: news coverage of the conflicts in Rwanda and Bosnia." Political Geography Vol. 15, No. 1:21-46.http://dx.doi.org/10.1016/0962$\underline{6298(95) 00041-0}$

Panagioutou, Nikos. 2005. "The Role of Mass Media in Public Policy: The Case of the Greek Press." Paper for $2^{\text {nd }}$ London School of Economics PhD Symposium on Modern Greece, June 10.

Patterson, Thomas C. 1997. Inventing Western Civilization. New York: Monthly Review Press.

Piliavin, Irving M., Judith Rodin, and Jayne Allyn Piliavin. 1969. "Good Samaritanism: An Underground Phenomenon?" Journal of Personality and Social Psychology Vol. 13, No. 4, pages 289-299. http://dx.doi.org/10.1037/h0028433

Power, Samantha. 2002. A Problem from Hell: America in the Age of Genocide. New York: Basic Books.

Robinson, Piers. 2002. The CNN-effect. The Myth of News, Foreign Policy and Intervention. London: Routledge.

Sadkovich, James J. 1998. The U.S. Media and Yugoslavia, 1991-1995. Westport: Praeger Publishers.

Sidahmed, Abdel Salam, Walter C. Soderlund, and E. Donald Briggs. 2010. The Responsibility To Protect in Darfur: The Role of Mass Media. Plymouth, U.K.: Lexington Books.

Soroka, Stuart N. 2002. "Issue Attributes and Agenda-Setting by Media, the Public, and PolicyMakers in Canada." International Journal of Public Opinion Research. Vol. 14, No. 3: pages 264-85. http://dx.doi.org/10.1093/ijpor/14.3.264

Staub, Ervin. 2003. The Psychology of Good and Evil. New York: Cambridge University Press. http://dx.doi.org/10.1017/CBO9780511615795

Sykes, Gresham M. and David Matza. 1957. "Techniques of Neutralization: A Theory of Delinquency." American Sociological Review Vol. 22, No. 6: pages 664-670. http://dx.doi. org/10.2307/2089195

Thompson, Allan, editor. 2007. The Media and the Rwanda Genocide. London: Pluto Press.

UN World Summit Outcome Document: G.A. Res. A/Res/60/1 (Oct. 24, 2005).

Todorova, Maria. 1994. "The Balkans: From Discovery to Invention." Slavic Review Vol. 53, No. 2: 453-482. http://dx.doi.org/10.2307/2501301

Todorova, Maria. 1997. Imagining the Balkans. Oxford: Oxford University Press 